\title{
Impact of Performance Appraisal Strategy on Employee's Job Satisfaction in Ghana Technology University (2015)
}

\author{
Emelia Ohene Afriyie \\ Lecturer of Accra Polytechnic \\ Department of Secretaryship and Management Studies
}

\begin{abstract}
Rapid change and development of human resource management practices have made the existence of efficient and effective organisational performance appraisal system for the organisation inevitable. This study is designed to study the relationship between the performance appraisal (PA) strategy and its impact on employee's job satisfaction. Questionnaire was used for this purpose and the study was conducted at Ghana Technology University Main Campus. Statistical population for this study is $\mathbf{6 0}$ employees of Ghana Technology University. SPSS software was used for the analysis. The major findings were that correlation coefficient for the relationship between performance appraisal strategy and employees' job satisfaction was, however, positive at 0.001. Also, it was found that the relationships between performance appraisal strategy and the employees' job satisfaction were statistically significant at alpha $(\alpha)=$ 0.01. These indicate, there are positive influences or impact of performance appraisal and employees' job satisfaction and performance appraisal strategy on job satisfaction and satisfaction on overall position in Ghana Technology University. It is recommended that performance appraisal should be conducted with both managers and employees of Ghana Technology University.
\end{abstract}

Keywords: Performance, Appraisal Strategies, and Job Satisfaction.

\section{INTRODUCTION}

Ali, Mahdi and Malihe (2012), identify that "dramatic changes in the knowledge management area have converted the nature of performance evaluation system to an inevitable issue, so that the lack of appraisal system in the organisation considers as one of the symptoms of the organisational diseases. Every organisation has an objective and those objectives are supposed to be achieved within a stipulated time. The tool that is used to check the performance of workers is called Performance Appraisal (PA). According to Behri and Patron (2008), Performance evaluation today is known as a strategic approach for integration of human resources activities together with policies of business and the organisations use advanced and complex methods for assessing the performance of their employees. Performance appraisal is a tool that is used in organisations to evaluate the assessment of employees. It helps the manager to guide its work toward the achievement of organisational goals and help the check the strength and weakness of the employees. It also assists to know who is accountable for a work done.

"In many organisations, - but not all -appraisal results are used, either directly or indirectly, to help determine reward outcomes. That is, the appraisal results are used to identify the better performing employees who should get the majority of available merit pay increases, bonuses and promotion" (Alvi, Surani, \& Hirani, 2013). Employees' performance can be reviewed to help know who need training and the kind of training needed to boost performance and when performance appraisal is properly done, it is an effective planning tool for managers and 
provides important feedback to employees. Appraisal can be used to reward, but also to identify potential for training and development (Dama 2007, p.207).

\section{STATEMENT OF THE PROBLEM}

According to Alvi, et al, (2013), one of the major causes of collapsing organisation is "non alignment of responsibility and accountability". This occurs when employees are given tasks to perform and they are not liable of their responsibilities and duties. Some managers find it difficult to tell workers the core value of the organisation which makes it difficult for a worker to know what is expected of them. They develop the performance appraisal without the involvement of the people concerned. Employees sometimes are not aware of the goals of the organisation and do not know what is appraisal and what it is used for. Dama (2007) opined that "it is often the case that in some organisations someone has designed a form or a procedure, issued it and said from the first of next month, there shall be performance reviews." They are only aware that it is used to check on those who are not performing well in the organisation but not aware that well performed worker is also rewarded. They only know that getting to end of every year document or some papers are given to them to fill. Employees do not receive feedback of the appraisal to know what to do later and this brings dissatisfaction.

Research show that many organisations are not satisfied with their employees' performance evaluation plan (Ali, Mahdi and Malihe 2012). Fletcher (2001) opined that performance evaluation systems has not been successful in creating motivation and improvement of employees performance and it is against this background that a research is conducted to assess the effect of appraisal on employee's job satisfaction.

\section{RESEARCH OBJECTIVES}

Objectives of this study have been divided into general and specific objective. The general objective of the study is to identify the significant relationship of performance appraisal and employee's job satisfaction. Specifically,

1. To find out the impact of employees performance appraisal in Ghana Technology University;

2. To analyse the effect of performance appraisal on employee's job satisfaction.

\section{RESEARCH QUESTIONS}

The research seeks to answer the following questions;

1. What is the impact of employee's performance appraisal?

2. What is the effect of performance appraisal on employee's job satisfaction?

\section{Hypothesis}

H0: Performance appraisal does not lead to employees' job satisfaction.

H1: Performance appraisal lead to employees' job satisfaction.

Significance of the Study This research offers various benefits to academia, policy makers and practitioners. This study will add to the scientific knowledge on performance appraisal and employees job satisfaction. Secondly the study is in attempt to help address the dearth of information on performance appraisal and job satisfaction. The findings of this research will help human resource managers of Ghana Technology University to be able to identify the satisfaction level impacts on the employee's productivity. It will also help to know the kind of compensation that will be given to each employee according to his or her performance. It will help policy makers to identify the job satisfaction level among the employees of Ghana Technology University College. 


\section{DELIMITATION}

The study should have sample from all employees from all GTUC campuses. However, the study focused on the performance appraisal strategy and employees job satisfaction (GTUC) Main Campus because research need to be limited to a specific area. The research was interested in the employees' satisfaction. Though employees were likely to have other problems, the researcher decided to concentrate on performance appraisal strategy. Alvi, Surani and Hirani (2013) from the view point of the organisation, one of the most important reasons for having a system of performance appraisal is to establish and uphold the principle of accountability and from the view point of the employee it tell them what to do, how to do it, how to improve performance and rewards for doing well. Hornqren, Faster and Datar (2002) state it is significant to evaluate performance from the perspective of the organisation and individual.

\section{LIMITATION}

Every research has certain limitations which affect the extent to which the findings can be generalised and this study is no exception. The drawing of the respondents from only GTUC Main Campus also impeded the degree of generalisation of the findings of the study. Nevertheless, since employees of the Main Campus are more than the Abaka suburb staff, it can be argued that the findings of this study could be applied to all GTUC employees.

The study also included all the employees of GTUC irrespective of the number of years the respondent had worked with GTUC. This is also a likely to affect the results since now employees would not be in a position to have much experience of this practice.

\section{Background of performance appraisal}

\section{LITERATURE REVIEW}

The history of performance appraisal is quite brief. It started in the early 20th century and can be traced to Taylor's pioneering Time and Motion studies. It is a technique use to evaluate performance of workers. As a distinct and formal management procedure used in the evaluation of work performance, appraisal really dates back from the time of the Second World War - not more than 60 years ago. Yet in a broader sense, the practice of appraisal is a very ancient art. In the scale of things historical, it might well lay claim to being the world's second oldest profession. There is, says Dulewicz (1989), "... a basic human tendency to make judgements about those one is working with, as well as about oneself." Appraisal, it seems, is both inevitable and universal. In the absence of a carefully structured system of appraisal, people will tend to judge the work performance of others, including subordinates, naturally, informally and arbitrarily. The human inclination to judge can create serious motivational, ethical and legal problems in the workplace. Without a structured appraisal system, there is little chance of ensuring that the judgements made will be lawful, fair, defensible and accurate.

\section{Performance Appraisal}

Performance appraisal according to Dessler (2008), it is any procedure that involves setting work standards, assessing the employees' actual performance relative to those standards and providing feedback to employees with the aim of motivating him/her to eliminate performance deficiencies or to continue to perform above expectation. Performance appraisal is the way through which employees perform their duties and the evaluation is judging the performance of employees (Scott, 2009). According to Armstrong (2007), Performance appraisal can be defined as the formal assessment and rating of individuals by their managers at, usually, an annual review meeting. Performance appraisal is the measurement of work and its results by using the scale and index that we can measure the desired quantity and quality with precision 
and free of personal judgements and vague criteria of evaluation (Ali, Mahdi \&Malihe 2012). Aquinas (2009) summed everything up by defining performance appraisal as a method of evaluating the behaviour or employees in the work spot, normally including both the quantitative and qualitative aspects of job performance.

\section{Importance of Performance Appraisal}

According to Dama (2007) "The effective performance of people in an organisation depends on two processes working in parallel. The matching of individuals in terms of skills, knowledge and interest to current and anticipated job demands". The development of job activities to match the skills and interest of the individuals doing them is the duty of the manager. These processes are sometimes in conflict, but is monitoring, developing and maintaining the balance for the team. Good managers do this as part of their day-to-day management, delegation and supervision. But an effective employee is not just a skill tap turned on and off by management. He also checks and develops his own skills and interests against the job demands. Like all selfregulating, self-controlling systems, both the manager and the employee need clear goals and feedback to be successful. Although they may work together on a continuing basis, if can only help to take a time-out from the day-to-day pressures to check on the goals and give each other the feedback and guidance in a sensible relevant way.

Alvi, et al, (2013) from the view point of the organisation, one of the most important reasons for having a system of performance appraisal is to establish and uphold the principle of accountability and from the view point of the employee, it tells them what to do, how to do it, how to improve performance and rewards for doing well. Hornqren, et al, (2002) stated, it is significant to evaluate performance from the perspective of the organisation and individual. From the organisation perspective, the "goal" is something that organisation wants and the "result" is something that organisation wants and the "result" is what should be done; while from the individual view, "effect" is what that person does and "result" is the consequence of his effort and what he expects to get in return for his effort is "reward". Byars and Rue (2004) stipulated that whatever the method of performance appraisal an organisation uses it must be job related; therefore, prior to selecting a performance appraisal method an organisation must conduct job analysis and develop job description

\section{METHODOLOGY}

Population is a group of individual persons' objects, or items from which samples are taken for measurement. The population consists of all workers of Ghana Technology University College Main Campus. GTUC was chosen because of its outstanding performance, its rapid expansion and ability to compete with the old Universities. The sample for the study comprised 60 respondents and convenience sampling was used. Research instruments are the direct means or tools used by a researcher to obtain information for a study. Specifically, the questionnaire was used because the research gathered the view of employees. Questionnaire is research instruments consisting of a series of questions and other prompts for the purpose of gathering information from respondents. The researcher adopted this instrument because it is cheaper to administer. However, it was time involving in developing them. The questionnaire is made up of three parts ranging from A-C, covering twenty (20) items. The A part of the questionnaire elicited personal background information regarding age, highest education, department, position and years of service. The part B of the questionnaire focused on impact of employee's performance appraisal and the part $\mathrm{C}$ the final part dealt with the job satisfaction measures consist of 14 questions scored on a likert scale format. According to Ackroyd and Hughes (1985) questionnaire can be carried out by the researcher or by any number of people with limited effect to its validity and reliability. The results of the questionnaires can usually be 
quickly and easily quantified by either a researcher or through the use of a software package and be analysed more 'scientifically' and objectively than other forms of research. When data has been quantified, it can be used to compare and contrast other research and may be used to measure change. The data required for the study were both primary and secondary. The data was collected through the design and administration of questionnaire. A self-administered questionnaire was filled by 60 respondents (in different department of Ghana Technology University College). Not every respondent got equal chance to become the part of this research and the research was conducted on the basis of convenience. Text analytics for surveys (SPSS) reviewed was used in the analysis of the data that were collected in this research as the researcher deemed it the most appropriate given its versatility and considering the nature of the data collected. The questionnaires were administered directly to respondents in their offices and they were collected after six weeks. The target group was employees of Ghana Technology University College and participation in the study was voluntary and anonymous.

\section{DATA PRESENTATION AND ANALYSIS}

The main task of the researcher in this chapter is the presentation and analysis of the data collected from 60 respondents from Ghana Technology University College. The data is analysis with regards to findings from data collected. This section presents the analysis of data on questionnaire related to personal detail, impact of employee's performance appraisal and effect of performance appraisal of employee's job satisfaction.

\section{PERSONAL DETAILS}

Table 1: Gender of Respondents

\begin{tabular}{lcccc}
\hline Gender & Frequency & Percent & Valid Percent & Cumulative Percent \\
\hline Male & 46 & 76.7 & 76.7 & 76.7 \\
Female & 14 & 23.3 & 23.3 & 100.0 \\
\hline Total & 60 & 100.0 & 100.0 & \\
\hline
\end{tabular}

Source: Field data, 2014

Table 1 shows the gender of workers in Ghana Technology University. Forty-six (76.6\%) of the respondents were male whereas fourteen $(23.3 \%)$ were female. This shows that there more males workers as compared to females.

Table 2: Age Distribution of Respondents

\begin{tabular}{lcccc}
\hline Age Distribution & Frequency & Percent & Valid Percent & Cumulative Percent \\
\hline 18-20 years & 0 & 0.0 & 0.0 & 0.0 \\
21-30 years & 28 & 46.7 & 46.7 & 46.7 \\
31-40 years & 25 & 41.7 & 41.7 & 88.3 \\
41-50 years & 3 & 5.0 & 5.0 & 93.3 \\
51-60 years & 4 & 6.7 & 6.7 & 100.0 \\
\hline Total & 60 & 100.0 & 100.0 & \\
\hline
\end{tabular}

Source: Field data, 2014

Respondents' age were also analysed. Table 2 looks at the age distribution of respondents. Twenty-eight (46.7\%) of the respondents were aged between 21 and 30; 25 respondents (41.7\%) were between 31 and 40 years; 3 respondents (5.0\%) were between 41 and 50 years and 4 representing (6.7\%) were between 51 and 60 years. None of the respondent was in the 
year group of $18-20.88 .3 \%$ of the respondents were between $21-40$ years and this shows that the respondents are in their youthful age and the University has good future.

Table 3: Level of Education of Respondents

\begin{tabular}{lcccc}
\hline Educational Qualification & Frequency & Percent & Valid Percent & Cumulative Percent \\
\hline Secondary & 7 & 11.7 & 11.7 & 11.7 \\
Tertiary & 49 & 81.7 & 81.7 & 93.3 \\
Post graduate & 4 & 6.7 & 6.7 & 100.0 \\
\hline Total & 60 & 100.0 & 100.0 & \\
\hline
\end{tabular}

Source: Field data, 2014

The successful development of any institution depends on capabilities of her human resource base. The educational level of the people determines to a large extent the nature of responses and their understanding of the issues at stake. The ability of workers to combine different methods especially modern technology improves their performance at work and hence their output will be very high. Data gathered from the field indicate that out of 60 respondents, 47 representing (81.7\%) had Degree or Masters Qualification. Four (6.7\%) of the respondents hold Doctor of Philosophy (PhD) with only 7 (11.7\%) holding Secondary School Certificate.

Table 4: Department of Respondents

\begin{tabular}{lcccc}
\hline Department & Frequency & Percent & Valid Percent & Cumulative Percent \\
\hline Research and Development & 9 & 15.0 & 15.0 & 15.0 \\
General Administration & 20 & 33.3 & 33.3 & 48.3 \\
ICT & 10 & 16.7 & 16.7 & 65.0 \\
Human Resource & 5 & 8.3 & 8.3 & 73.3 \\
Security & 9 & 15.0 & 15.0 & 88.3 \\
Engineering & 3 & 5.0 & 5.0 & 93.3 \\
Finance & 4 & 6.7 & 6.7 & 100.0 \\
\hline Total & 60 & 100.0 & 100.0 & \\
\hline
\end{tabular}

Source: Field data 2014

The department of respondents is presented in Table 4. Form the table 4, it can be found that $20(33.3 \%)$ of the respondents are in the General Administration; 10 (16.7\%) are from ICT, 9 (15.0) are from security and Research and Development respectively. Five (8.3\%) are from Human

Resource; 4 and 3 respectively are in Finance and Engineering department.

Table 5: Duties of Respondents

\begin{tabular}{lcccc}
\hline Position & Frequency & Percent & Valid Percent & Cumulative Percent \\
\hline Clerical/Administrative & 24 & 40.0 & 40.0 & 40.0 \\
Technician & 6 & 10.0 & 10.0 & 50.0 \\
Managerial & 3 & 5.0 & 5.0 & 55.0
\end{tabular}




\begin{tabular}{lcccc} 
Accounting & 4 & 6.7 & 6.7 & 61.7 \\
Security & 9 & 15.0 & 15.0 & 76.7 \\
System Administrator & 1 & 1.7 & 1.7 & 78.3 \\
Driver & 1 & 1.7 & 1.7 & 80.0 \\
Lecturer & 12 & 20.0 & 20.0 & 100.0 \\
\hline Total & 60 & 100.0 & 100.0 & \\
\hline
\end{tabular}

Source: Field data, 2014

Respondents were further asked to indicate their duties in the University. The details have been provided in Table 5. Twenty-four (40.0\%) were Clerical and Administrative; 12 (20\%) were lecturers; 9 (15.0\%) were security; 4(6.7\%) were Accounting; 3 (5.0\%) were Managerial; $1(1.7 \%)$ was a System Administrator and Driver respectively. This shows that almost all the positions were captured.

Table 6: Length of Service in the University

\begin{tabular}{lcccc}
\hline Working experience & Frequency & Percent & Valid Percent & Cumulative Percent \\
\hline Less than a year & 19 & 31.7 & 31.7 & 31.7 \\
1-3 years & 25 & 41.7 & 41.7 & 73.3 \\
4-6 years & 14 & 23.3 & 23.3 & 96.7 \\
7-9 years & 2 & 3.3 & 3.3 & 100.0 \\
\hline Total & 60 & 100.0 & 100.0 & \\
\hline
\end{tabular}

Source: Field data 2014

It is clear from the Table 6 that the modal length of service is between 1 and 3 years (41.7\%). This indicates that most of the respondents had served the University for a Maximum of 3 years and the minimum of one year. Only 2 representing (3.3\%) of the respondents had served the University for over seven years. Fourteen (23.3\%) have served for 4 and 6 years; 19 $(31.7 \%)$ have served for less than one year. The University is a young one and this indicate that it is increasing and diversing the human resource base.

Table 7: Receiving of Adequate Training to do Job Well

\begin{tabular}{lcccc}
\hline On the job training & Frequency & Percent & Valid Percent & Cumulative Percent \\
\hline Strongly agree & 18 & 30.0 & 30.0 & 30.0 \\
Agree & 32 & 53.3 & 53.3 & 83.3 \\
Not agree nor disagree & 5 & 8.3 & 8.3 & 91.7 \\
Disagree & 3 & 5.0 & 5.0 & 96.7 \\
Strongly agree & 2 & 3.3 & 3.3 & 100.0 \\
\hline Total & 60 & 100.0 & 100.0 & \\
\hline
\end{tabular}

Source: Field data 2014

To ascertain whether staff received adequate training to do their job well, they were asked to indicate their agreement or disagreement. Fifty (83.3\%) were in favour that they received adequate training to help them do their job well. Five (8.3\%) said they do not received 
adequate training to help them do their job. Five $(8.3 \%)$ did not say either they received enough training or not. The results indicate the Ghana Technology University gives her workers adequate training to do their job very well. This will help young University like this to compete with the old Universities.

Table 8: Often Worry about Work Issues when at Home

\begin{tabular}{lcccc}
\hline & Frequency & Percent & Valid Percent & Cumulative Percent \\
\hline Strongly agree & 11 & 18.3 & 18.3 & 18.3 \\
Agree & 22 & 36.7 & 36.7 & 55.0 \\
somewhat agree & 18 & 30.0 & 30.0 & 85.0 \\
Disagree & 6 & 10.0 & 10.0 & 95.0 \\
Strongly disagree & 3 & 5.0 & 5.0 & 100.0 \\
\hline Total & 60 & 100.0 & 100.0 & \\
\hline
\end{tabular}

Source: Field data 2014

When asked if workers are worried about work issues when they are at home, 53 (85\%) were in the agreement that they do worry about work issues when they are out of work. Nine $(15.0 \%)$ said that they do not. This shows that workers of the Ghana Technology University have the University at heart and this can lead to performance because almost everybody think of the organisation.

Table 9: Performance Appraisal should be Conducted by both Managers and Employees

\begin{tabular}{lcccc}
\hline & Frequency & Percent & Valid Percent & Cumulative Percent \\
\hline Strongly agree & 25 & 41.7 & 41.7 & 41.7 \\
Agree & 29 & 48.3 & 48.3 & 90.0 \\
somewhat agree & 2 & 3.3 & 3.3 & 93.3 \\
Disagree & 4 & 6.7 & 6.7 & 100.0 \\
\hline Total & 60 & 100.0 & 100.0 & \\
\hline
\end{tabular}

Source: Field data 2014

With respect to how appraisal should be conducted in the University, the responses have been presented in Table 9. Fifty-four (90\%) of the respondents who form the majority reported that the University should conduct appraisal by both managers and employees. This affirmed the position of (Dama, 2007) appraisee and appraiser should come together, so that both can contribute to the assessment and plans for improvement and/or development. Six respondents representing (9.9\%) reported that appraisal should be conducted by only the managers. The result shows that majority of workers in Ghana Technology University want appraisal to be done by the Managers and employees. This affirms the research done by Hornqren, et al, (2002) state it is significant to evaluate performance from the perspective of the organisation and individual. 
Table 10: Sometimes Performance Appraisal does not Identify the Skilled Employees

\begin{tabular}{lcccc}
\hline & Frequency & Percent & Valid Percent & Cumulative Percent \\
\hline Strongly agree & 9 & 15.0 & 15.0 & 15.0 \\
Agree & 34 & 56.7 & 56.7 & 71.7 \\
Somewhat agree & 8 & 13.3 & 13.3 & 85.0 \\
Disagree & 7 & 11.7 & 11.7 & 96.7 \\
Strongly disagree & 2 & 3.3 & 3.3 & 100.0 \\
\hline Total & 60 & 100.0 & 100.0 & \\
\hline
\end{tabular}

Source: Field data 2014

Table 10 elicited responses on whether performance appraisal does not identify the skilled employees. Fifty-one (85.0\%) who form Majority agreed that sometimes performance appraisal does not identity the skilled employees so other methods should be adopted to use it to check their performances. Nine (15.0\%) disagree that sometimes performance appraisal does not identity the skill employees.

Table 11: Managers should also Use Informal Appraisal System to Observe employees Behaviour

\begin{tabular}{lcccc}
\hline & Frequency & Percent & Valid Percent & Cumulative Percent \\
\hline Strongly agree & 19 & 31.7 & 31.7 & 31.7 \\
Agree & 30 & 50.0 & 50.0 & 81.7 \\
Somewhat agree & 5 & 8.3 & 8.3 & 90.0 \\
Disagree & 6 & 10.0 & 10.0 & 100.0 \\
\hline Total & 60 & 100.0 & 100.0 & \\
\hline
\end{tabular}

Source: Field data 2014

On condition of managers using informal appraisal systems to observe employees behaviour and reward them. Forty-nine (81.3\%) said informal appraisal system should be developed to assess the behaviour of employee. Eleven (17.7\%) said the formal method still hold. From Table 10, Majority agreed that sometimes performance appraisal does not identity the skilled employees so other methods should be adopted to use it to check their performances.

Table 12: Do You Get the Feed Back of Your Performance After Appraisal

\begin{tabular}{lcccc}
\hline & Frequency & Percent & Valid Percent & Cumulative Percent \\
\hline Always & 12 & 20.0 & 20.0 & 20.0 \\
Sometimes & 28 & 46.7 & 46.7 & 66.7 \\
Never & 20 & 33.3 & 33.3 & 100.0 \\
\hline Total & 60 & 100.0 & 100.0 & \\
\hline
\end{tabular}

Source: Field data 2014

Respondents were given the opportunity to indicate whether they get feedback after performance appraisal. Twelve (20.0\%) acknowledged that they always receive feedback after 
appraisal, 28 (46.6\%) said sometimes they do receive feedback after appraisal. Twenty $(33.3 \%)$ said they had never received any feedback from their employer. Employees do not receive feedback of the appraisal to know what to do later and this bring dissatisfaction (Dame, 2007). According to Mathis, and Jackson, (1994, p 328) "Performance Appraisal is the process of evaluating how well employees do their jobs compared with a set of standards and communicating that information to employees". Which means that they are not aware whether they are performing or not and this can affect their performance.

Table 13: Should Performance Appraisal be Used to Develop and Reward Effective Teamwork

\begin{tabular}{lcccc}
\hline & Frequency & Percent & Valid Percent & Cumulative Percent \\
\hline Always & 32 & 53.3 & 53.3 & 53.3 \\
Sometimes & 26 & 43.3 & 43.3 & 96.7 \\
Never & 2 & 3.3 & 3.3 & 100.0 \\
\hline Total & 60 & 100.0 & 100.0 & \\
\hline
\end{tabular}

Source: Field data 2014

Table 18 reveals that majority of the respondents (96.7\%) wished that performance appraisal should be used to develop and reward effect teamwork. Less than (4\%) said they never wish so. Which means that workers of Ghana Technology believed that performance appraisal is a good tool to assess the effectiveness of workers and reward them. The appraisal scheme can also be used for the basis of a review of financial reward (Mullins, 2005).

Table 14: Do You Agree with the Performance Appraisal Results You Get

\begin{tabular}{lcccc}
\hline & Frequency & Percent & Valid Percent & Cumulative Percent \\
\hline Always & 6 & 10.0 & 10.0 & 10.0 \\
Sometimes & 50 & 83.3 & 83.3 & 93.3 \\
Never & 4 & 6.7 & 6.7 & 100.0 \\
\hline Total & 60 & 100.0 & 100.0 & \\
\hline
\end{tabular}

Source: Field data 2014

Majority of workers (83.3\%) reported that they do sometimes agree with the performance appraisal results. Six representing (10.0\%) reported that always agree to the performance appraisal results. Only $4(6.7 \%)$ reported that they never agree to the results. This shows that even those who did not receive feedback on their performance believed that the results is authentic because Table 18 reveals that majority of the respondents (96.7\%) wished that performance appraisal should be used to develop and reward effective teamwork.

Table 15: Does Performance Appraisal Strategy Leads to Job Satisfaction

\begin{tabular}{lcccc} 
& Frequency & Percent & Valid Percent & Cumulative Percent \\
\hline Always & 10 & 16.7 & 16.7 & 16.7 \\
Sometimes & 45 & 75.0 & 75.0 & 91.7 \\
Never & 5 & 8.3 & 8.3 & 100.0 \\
\hline Total & 60 & 100.0 & 100.0 & \\
\hline
\end{tabular}

Source: Field data 2014 
Job satisfaction was also assessed. From the table 55 (91.7\%) of the respondents who form the majority of respondents confirmed that the University appraisal strategy leads to Job Satisfaction. Five which is less then (9\%) said that performance appraisal system used by the University does not lead to job satisfaction. The result shows that majority of respondents have the trust in the appraisal strategy used by the University.

Table 16: Does Performance Appraisal Strategy Serves on the Basis of Promotion

\begin{tabular}{lcccc}
\hline & Frequency & Percent & Valid Percent & Cumulative Percent \\
\hline Always & 5 & 8.3 & 8.3 & 8.3 \\
Sometimes & 49 & 81.7 & 81.7 & 90.0 \\
Never & 6 & 10.0 & 10.0 & 100.0 \\
\hline Total & 60 & 100.0 & 100.0 & \\
\hline
\end{tabular}

Source: Field data 2014

On the issue of performance appraisal serves on the basis of promotion, $49(81.7 \%)$ indicated that it sometimes used as a basis for promotion. Five respondents representing (8.3\%) said they always use performance appraisal as strategy for promotion. Six (10.0\%) said they never use it but were not asked for the reasons why the appraisal is not for the basis of promotion. A comprehensive appraisal system can provide decisions such as those relating to allocation of duties and responsibilities, pay, empowerment and levels of supervision, promotions, training and development needs and terminations (Mullins, 2005).

Table 17: Would You Refer a Relative/Friend to Apply for a Job at Ghana Technology University College

\begin{tabular}{lcccc}
\hline & Frequency & Percent & Valid Percent & Cumulative Percent \\
\hline Definitely & 25 & 41.7 & 41.7 & 41.7 \\
Probably & 27 & 45.0 & 45.0 & 86.7 \\
Not sure & 8 & 13.3 & 13.3 & 100.0 \\
\hline Total & 60 & 100.0 & 100.0 & \\
\hline
\end{tabular}

Source: Field data 2014

When asked whether respondents will refer their friend or relative to apply for a job at Ghana Technology University. Fifty-two representing (86.7\%) said they will definitely or probably refer their relatives or friends for a job at Ghana Technology University. Eight respondents representing (13.3\%) said they are not sure. This affirms that Ghana Technology University workers are satisfied with organisation.

Table 18: In Your opinion Which Time Duration should Performance Appraisal be Conducted

\begin{tabular}{lcccc}
\hline & Frequency & Percent & Valid Percent & Cumulative Percent \\
\hline Once a year & 23 & 38.3 & 38.3 & 38.3 \\
Twice a year & 28 & 46.7 & 46.7 & 85.0 \\
Four time a year & 8 & 13.3 & 13.3 & 98.3 \\
Every month & 1 & 1.7 & 1.7 & 100.0 \\
\hline Total & 60 & 100.0 & 100.0 & \\
\hline
\end{tabular}

Source: Field data 2014 
From Table 18, 28 respondents representing (46.1\%) said the appraisal should be conducted twice a year because there is assessment before examination. Twenty-three $(38.3 \%)$ indicated that once a year is enough to assess their performance but must be done with them. Eight $(13.3 \%)$ said it should be like continuous assessment, four times a year will do. Only one person said every month. The table shows that a great number but not up to half of the respondents said twice is enough.

Table 19: Satisfaction with the Current Performance Appraisal System of Ghana Technology University College

\begin{tabular}{lrrrr}
\hline & Frequency & Percent & Valid Percent & Cumulative Percent \\
\hline Strongly satisfied & 3 & 5.0 & 5.0 & 5.0 \\
Satisfied & 39 & 65.0 & 65.0 & 70.0 \\
Somewhat satisfied & 13 & 21.7 & 21.7 & 91.7 \\
Dissatisfied & 5 & 8.3 & 8.3 & 100.0 \\
\hline Total & 60 & 100.0 & 100.0 & \\
\hline
\end{tabular}

Source: Field data 2014

Respondents were also required to indicate their level of satisfaction on the current performance appraisal system used in Ghana Technology University. Thirty-nine respondents indicated that they were satisfied, $13(21.3 \%)$ indicated that they were somewhat satisfied and $3(5.0 \%)$ indicated that they were strongly satisfied. This shows that majority of the respondents are satisfied with the University's performance appraisal just that it should be conducted with both managers and employees and must be done twice a year instead of once.

Table 20: Overall Satisfied of Position in Ghana Technology University College

\begin{tabular}{lcccc}
\hline & Frequency & Percent & Valid Percent & Cumulative Percent \\
\hline Strongly satisfied & 5 & 8.3 & 8.3 & 8.3 \\
Satisfied & 42 & 70.0 & 70.0 & 78.3 \\
Somewhat satisfied & 8 & 13.3 & 13.3 & 91.7 \\
Dissatisfied & 5 & 8.3 & 8.3 & 100.0 \\
\hline Total & 60 & 100.0 & 100.0 & \\
\hline
\end{tabular}

Source: Field data 2014

Table 20 shows that overall 5 (8.3\%) were strongly satisfied with their position. Forty-two $(70.0 \%)$ were satisfied with their position, 8 (13.3) indicated that they were somewhat satisfied where as $5(8.3 \%)$ were dissatisfied about their position. Overall 55 respondents indicated that they are one way or the other satisfied with their positions in the University. This shows that workers of Ghana Technology University are very much satisfied.

\section{TESTING OF HYPOTHESIS}

The purpose of this hypothesis was to ascertain whether performance appraisal leads to employees' job satisfaction.

\section{Hypothesis}

1. H0: Performance appraisal does not leads to employees' job satisfaction. 


\section{H1: Performance appraisal leads to employees' job satisfaction.}

The two-tailed hypothesis was statistically tested using Pearson's correlation coefficient.

Table 21: Correlations

\begin{tabular}{|c|c|c|c|c|c|c|c|c|}
\hline & & $\begin{array}{c}\text { Agree } \\
\text { performance } \\
\text { appraisal } \\
\text { results }\end{array}$ & $\begin{array}{l}\text { Performance } \\
\text { appraisal } \\
\text { strategy to } \\
\text { job } \\
\text { satisfaction }\end{array}$ & $\begin{array}{l}\text { Performance } \\
\text { appraisal } \\
\text { strategy as a } \\
\text { basis of } \\
\text { promotion }\end{array}$ & $\begin{array}{l}\text { Refer a } \\
\text { relative/friend } \\
\text { to for a job in } \\
\text { GTUC }\end{array}$ & $\begin{array}{l}\text { Time duration } \\
\text { performance } \\
\text { appraisal be } \\
\text { conducted }\end{array}$ & \begin{tabular}{|l|} 
Satisfaction \\
with the \\
current \\
performance \\
appraisal \\
system
\end{tabular} & $\begin{array}{l}\text { Overall } \\
\text { satisfaction } \\
\text { with } \\
\text { position in } \\
\text { GTUC }\end{array}$ \\
\hline \multirow{3}{*}{$\begin{array}{l}\text { Agree } \\
\text { performance } \\
\text { appraisal results } \\
\text { Q14 }\end{array}$} & $\begin{array}{l}\text { Pearson } \\
\text { Correlation }\end{array}$ & 1 & $.402^{* *}$ & .195 & .205 & .032 & $.566^{* *}$ & $.487^{* *}$ \\
\hline & $\begin{array}{l}\text { Sig. } \\
\text { tailed })\end{array}$ & & .001 & .136 & .116 & .810 & .000 & .000 \\
\hline & $\mathrm{N}$ & 60 & 60 & 60 & 60 & 60 & 60 & 60 \\
\hline \multirow{3}{*}{\multicolumn{2}{|c|}{$\begin{array}{ll}\text { performance } & \text { Pearson } \\
\text { appraisal } & \text { Correlation } \\
\text { strategy leads to } & \text { Sig. } \\
\text { job satisfaction } & \text { tailed) } \\
\text { Q15 } & \text { N } \\
& \end{array}$}} & $.402^{* *}$ & 1 & $.481^{* *}$ & .029 & & $.322^{*}$ & $.338^{* *}$ \\
\hline & & .001 & & .000 & .827 & .704 & .012 & .008 \\
\hline & & 60 & 60 & 60 & 60 & 60 & 60 & 60 \\
\hline \multirow{3}{*}{\multicolumn{2}{|c|}{$\begin{array}{|ll|}\text { performance } & \text { Pearson } \\
\text { appraisal } & \text { Correlation } \\
\text { strategy serves } & \text { Sig. } \\
\text { on the basis of } & \text { tailed) } \\
\text { promotion Q15 } & \mathrm{N} \\
& \mathrm{N} \\
\end{array}$}} & .195 & $.481^{* *}$ & 1 & -.211 & -.148 & .149 & .208 \\
\hline & & .136 & .000 & & .105 & .259 & .257 & .111 \\
\hline & & 60 & 60 & 60 & 60 & 60 & 60 & 60 \\
\hline \multirow{3}{*}{\multicolumn{2}{|c|}{ 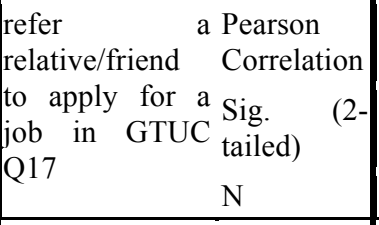 }} & .205 & .029 & -.211 & 1 & .110 & $.371^{* *}$ & $.263^{*}$ \\
\hline & & .116 & .827 & .105 & & .402 & .004 & .042 \\
\hline & & 60 & 60 & 60 & 60 & 60 & 60 & 60 \\
\hline \multirow{3}{*}{\multicolumn{2}{|c|}{ 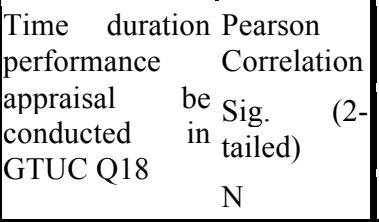 }} & .032 & -.050 & -.148 & .110 & 1 & .076 & .251 \\
\hline & & .810 & .704 & .259 & .402 & & .564 & .053 \\
\hline & & 60 & 60 & 60 & 60 & 60 & 60 & 60 \\
\hline \multirow{3}{*}{$\begin{array}{l}\text { Satisfaction } \\
\text { with the current } \\
\text { performance } \\
\text { appraisal system } \\
\text { Q19 }\end{array}$} & $\begin{array}{l}\text { Pearson } \\
\text { Correlation }\end{array}$ & $.566^{* *}$ & $.322^{*}$ & .149 & $.371^{* *}$ & .076 & 1 & $.795^{* *}$ \\
\hline & $\begin{array}{l}\text { Sig. } \\
\text { tailed })\end{array}$ & .000 & .012 & .257 & .004 & .564 & & .000 \\
\hline & $\mathrm{N}$ & 60 & 60 & 60 & 60 & 60 & 60 & 60 \\
\hline \multirow{3}{*}{$\begin{array}{lr}\text { Overall } & \mathrm{P} \\
\text { satisfaction } & \text { with } \mathrm{C} \\
\text { position } & \text { in } \mathrm{S} \\
\text { GTUC } & \text { tc } \\
& \mathrm{N}\end{array}$} & $\begin{array}{l}\text { Pearson } \\
\text { Correlation }\end{array}$ & $.487^{* *}$ & $.338^{* *}$ & .208 & $.263^{*}$ & .251 & $.795^{* *}$ & 1 \\
\hline & $\begin{array}{l}\text { Sig. } \\
\text { tailed })\end{array}$ & .000 & .008 & .111 & .042 & .053 & .000 & \\
\hline & $\mathrm{N}$ & 60 & 60 & 60 & 60 & 60 & 60 & 60 \\
\hline
\end{tabular}

**. Correlation is significant at the 0.01 level (2-tailed).

*. Correlation is significant at the 0.05 level (2-tailed).

As shown in the table 21, the test revealed that there was a high statistically significant positive correlation between employees appraisal with job satisfaction. 


\section{INTERPRETATION}

There is significant positive correlation between agreement with the performance appraisal result and performance appraisal strategy on job satisfaction. $(r=0.402, n=60, p<0.01)$. There is a high positive significant correlation between agreement with the performance appraisal and satisfaction of current performance appraisal system of position in Ghana Technology University. ( $\mathrm{r}=0.566, \mathrm{n}=60, \mathrm{p}<0.001)$. There is significant positive correlation between agreement with the performance appraisal result and satisfaction on overall position in Ghana Technology University.. $(\mathrm{r}=0.487, \mathrm{n}=60, \mathrm{p} 0.01)$. There is significant positive correlation between performance appraisal strategy on job satisfaction and performance appraisal strategy on the basis on promotion.. ( $\mathrm{r}=0.481, \mathrm{n}=60, \mathrm{p} 0.01)$. There is significant positive correlation between performance appraisal strategy on job satisfaction and satisfaction of current performance appraisal system of position in Ghana Technology University. . ( $r=0.322$, $\mathrm{n}=60$, $\mathrm{p}$ 0.05). There is significant positive correlation between performance appraisal strategy on job satisfaction and satisfaction on overall position in Ghana Technology University.. $(\mathrm{r}=0.338, \mathrm{n}=60, \mathrm{p}$ 0.01). There is significant moderate positive correlation between performance appraisal conducted by both managers and employees and satisfaction of current performance appraisal system of position in Ghana Technology University. $(r=0.263, n=60, p$ 0.01). There is significant moderate positive correlation between performance appraisal conducted by both managers and employees and satisfaction on overall position in Ghana Technology University. ( $\mathrm{r}=.(\mathrm{r}=0.263, \mathrm{n}=60, \mathrm{p}$ 0.05). There is significant high positive correlation between satisfaction of current performance appraisal system of position in Ghana Technology University and satisfaction on overall position in Ghana Technology University. $(\mathrm{r}=0.795, \mathrm{n}=60, \mathrm{p}$ 0.05)

On the basis of the statistical test the P-value of Pearson correlation between performance appraisal and employees' performance is 0.001 which is less than 0.01 mean the null hypothesis is rejected that performance appraisal lead to employees' job satisfaction.

\section{KEY FINDINGS}

From the above analysis of the questionnaire through the (SPSS) on the impact of employees' performance appraisal the study revealed that the, employees received adequate training to help them do their job well and they are always worried about work issues when they are out of work, employees also want appraisal to be conducted with the help of both managers and employees and how it is done do not sometimes identify the skilled employees so other methods like informal appraisal should be introduced and some employees do not receive feedback after appraisal. With regards to effect of performance appraisal on employees' job satisfaction, it was found that employees sometimes agree with the performance appraisal result and conformed that the University appraisal strategy leads to job satisfaction and sometimes also used as a promotion tool. Because they are satisfied with the performance appraisal strategy used they will refer or recommend their friends and relative for job at the University.

Moreover, the study revealed that by applying Pearson's correlation the result shows that the significant value (P-value) between both variables is 0.001 which is less than 0.01 , so we reject the null hypothesis that performance appraisal does not lead to employees' job satisfaction. It can be concluded that performance appraisal is significant to employees' job satisfaction. 


\section{CONCLUSION}

On the basis of the findings from the study, it could be concluded that: Performance appraisal strategy used by Ghana Technology University College lead to employees' job satisfaction because employees are satisfied with the strategy.

\section{RECOMMENDATION}

Following the research findings and conclusion, the following recommendations are made. The University should involve employees in the development of the performance appraisal and also give feedback of appraisal to employees help then know their performance. The study did not cover all the HRM functions as practised by the University. It is therefore recommended that further studies include those that were not covered such as training and development, recruitment, selection, compensation, human relation to ascertain how they also lead to job satisfaction.

\section{References}

Ackroyd, S., \& Hughes, J. A. (1981). Data Collection in Context. Longman.

Ali,S. B., Mahdi A. \& Malihe J.(2012).The Effect of Employees' Performance Appraisal Procedure on their Intrinsic Motivation International Journal of Academic Research in Business and Social Science. , Vol. 2, No. 12 ISSN: 22226990p. 161-170.

Alvi, M., Surani M. \& Hirani S. (2013). The effect of performance Evaluation on Employee's Job Satistaction in Pakistan Internatinal Airlines Corperation. Munich Personnal RePEc Archive (p.1-3) paper no 46415. www.academia.edu/6825275/proposal

Aquinas, P. G. (2009). Human Resource Management principle and practice, Vikas, New Delhi

Armstrong, M. (2007). Human Resource Management Practice (10thed) London and Philadelphia: Cambridge University Press.

Behrey,M. H. \& Parton, R.A.(2008). Performance appraisal - cultural fit and organizational outcomes within the U.A.E., Journal of American Academy of Business, 13(1), 166-76

Boateng, E. (2011). Effects of Performance Appraisal on the Achievement of Organizational Objectives: a Case Study of Manhyia District Hospital, Kumasi Published thesis.

Byars, L. L. \& Rue, L. W. (2004). Human Resource Management,(7thed) McGrew Irwin NY

Dama, E., (2007). Effective Management (2nded). New Jersey Publication , Kumasi Ghana

Dessler, G. (2008). Human Resource Management (11thed) Pearson International edition, Practice Hall, NJ

Fletcher,C. (2001).Performance appraisal and management: the developing research agenda Journal of Occupational and Organizational Psychology. 74(8),473-87.

Hornqren C., Faster G., \& Datar S. (2002). Cost Accounting: A Managerial Emphasis. 11 Prentice Hall, USA. http://en.wikipedia.org/wiki/Ghana_Technology_University_College accessed on 7 September 2014

http://search.tb.ask.com/search/GGmain.jhtml?searchfor=Types\%20of\%20Performance $\% 20 \mathrm{Appraisals \& cb=0D}$ \&p2 $={ }^{\wedge} 0 \mathrm{D}^{\wedge} \mathrm{xdm} 271^{\wedge} \mathrm{YYA}^{\wedge} \mathrm{gh} \& \mathrm{n}=77 \mathrm{FD} 35 \mathrm{DB} \& q i d=5 a 39 \mathrm{ce} 614 \mathrm{c} 364 \mathrm{c79b} 1594 \mathrm{e} 9 \mathrm{f} 10848 \mathrm{ca} 5 \&$ ord=3\&ptb=563D6771 -786B-4983-A8B1-

A557C7DDAD72\&ct=RR\&si=slot64774\&pg=GGmain\&ots=1405695883035\&pn=1\&ss=sub\&st=hp\&tpr=jrel 30 july 2014-07-18

Mathis, R. L., \& Jackson, J. H. (1995). Human resource management (7th ed.). NH: West Publishing Company. Mullins, L. J. (2005). Management and organisational behaviour (2nd ed.) London: Prentice Hall.

Scott, J. (2009). Performance appraisals that actually improvement performance, Career and Technical Education, Vol. 5, 22-25. 